University of Chicago Law School

Chicago Unbound

\title{
Argentine Constitutional Law. The Judicial Function in the Maintenance of the Federal System and the Preservation of Individual Rights
}

Max Rheinstein

Follow this and additional works at: https://chicagounbound.uchicago.edu/journal_articles

Part of the Law Commons

\section{Recommended Citation}

Max Rheinstein, "Argentine Constitutional Law. The Judicial Function in the Maintenance of the Federal System and the Preservation of Individual Rights," 57 Harvard Law Review 739 (1944).

This Article is brought to you for free and open access by the Faculty Scholarship at Chicago Unbound. It has been accepted for inclusion in Journal Articles by an authorized administrator of Chicago Unbound. For more information, please contact unbound@law.uchicago.edu. 
exceptions are abolished, and the provisions of the civil rules are adopted as to the preparation and form of the record on appeal. The first draft of the rules provided that the record on appeal need not be printed but that counsel might print as appendices to their briefs such parts thereof as they desired the appellate court to read, a provision now contained in the rules of the circuit courts of appeals for the first, second, third and fourth circuits and the District of Columbia. ${ }^{8}$ The second draft leaves this in the discretion of the circuit courts of appeals, providing that they may dispense with printing and review the proceedings on the typewritten record..$^{9}$

Appended to the rules are twenty-two forms, which serve to illustrate the simplicity of practice which it is the purpose of the rules to prescribe.

The Committee has done a monumental piece of work and has produced a code of criminal practice which is entitled to rank with the Civil Rules as one of the most important contributions ever made by the American bar to the development of the adjective law. This second preliminary draft is now before the bench and bar for further suggestions of amendment; but it is clear that few amendments, if any, are needed and that further tinkering with the Committee's work may do more harm than good. The Committee expects to have its report in final form and in the hands of the Supreme Court by September I; and it is to be hoped that the Court will act upon the report and adopt the rules with as little delay as possible and let the practice which they prescribe become the practice of the federal courts. Once in use there, it will furnish in every community a model of practice which we may confidently expect to be adopted ultimately by the courts of the several states.

JOHN J. PARKER.*

Argentine Constitutional Law. The Judicial Function in the Maintenance of the Federal System and the Preservation of Individual Rights. By Santos P. Amadeo. ${ }^{1}$ With a Foreword by L. S. Rowe. New York: Columbia University Press. I943. Pp. xii, 243. \$3.00.

Reception is a term well known to anthropologists as well as to legal historians. In the general anthropological sense the term signifies the conscious or unconscious acceptance of some cultural institution of one people by another people. Receptions of legal institutions or of entire legal systems have been frequent in the course of history. The cases most widely known are probably the reception of Roman law in Central Europe in the late middle ages and the reception of modern European law in the countries of the East. As to the former in particular, volumes

8 First Preliminary Draft, Rule 37 (b) (2).

9 Second Preliminary Draft, Rule 4I(a) (2).

* Senior Judge, United States Circuit Court of Appeals for the Fourth Circuit.

1 Professor of Political Science and Law, University of Puerto Rico. 
have been written about its causes, its course, and its consequences. Strangely neglected, although far-reaching in its implications, has been the reception of the constitutional system of the United States in the countries of Latin America. The system of political organization which was invented by the fathers of the American Constitution has been widely copied in the countries south of the Rio Grande. Of course, reception of the outward forms has not always meant the reception of the spirit in which the Constitution of the United States was conceived or in which it has subsequently been developed. What has become of the American institutions in the various new surroundings to which they were transplanted? Not very much has so far been known about this fascinating problem. Doctor Amadeo's book makes available to American readers a wealth of detailed material from the Argentine Republic, whose Constitution of $1853-1860$ was framed in conscious imitation of the Constitution of the United States. The half-century of Argentine history preceding this constitution was filled with almost constant unrest and a civil war in which the antagonism between provincial sovereignty and national centralization figured as a dominant issue. Constitutions of ephemeral duration followed each other in quick sequence, vacillating between extreme emphasis upon state rights and radical centralization. To the Argentinian leaders who after the downfall of the dictatorship of General Rosas were anxious to find a more permanent form for the consolidation of their nation, the Constitution of the United States presented itself as the most successful attempt to reconcile with one another the apparently contradictory principles of centralization and particularism and as the most durable establishment of a great nation as a republic. On the basis of the Argentinian literature, Doctor Amadeo describes the work of the convention, and he does not omit to mention the consternation which arose when the one copy of the Federalist suddenly disappeared. The Constitution of the United States, it is true, was not simply taken over literally. English and French institutions exerted some influence, and there were certain ideas of indigenous Argentinian progeny. But in the main features the American model was copied and, consequently, American constitutional law and practice have faithfully been followed and observed in later years. Since judicial control not only of the administration but also of legislation were among the institutions taken over from the United States, judicial decisions, especially of the federal supreme court in Buenos Aires, form a body of material on which the American influence can be studied in detail.

Doctor Amadeo's book constitutes a case study. With a truly prodigious effort he has collected and analyzed a large number of Argentinian decisions on those branches of constitutional law which are indicated in the subtitle of his book: the relations between the federal government and the provinces, and the preservation of individual rights. Looking over this material American lawyers will feel quite at home. The problems are familiar, the American texts and cases are referred to constantly, and 
strangely enough, even the factual situations which gave rise to the judicial controversies and which often appear so accidental are amazingly similar. Thus, for instance, the Argentinian case which definitely settled the power of the courts to declare a federal statute unconstitutional was concerned with a statute purporting to confer original jurisdiction upon the federal supreme court; and intergovernmental tax immunity was settled in a case involving the attempt of a province to tax the notes issued by the national bank.

The Argentinian Constitution of I853-1860 was adopted before the Fourteenth Amendment was added to the Constitution of the United States. Even in the absence of an exactly analogous provision, however, the Argentine supreme court seems to have followed the American cases in its efforts to protect personal and, particularly, property rights. The well-known American cases of the United States Supreme Court's most ardent period of property protection were faithfully cited and followed in the Argentine. Whether the recent trends of American adjudication will find an equal counterpart remains to be seen.

Professor Amadeo stresses and probably overestimates the similarities between Argentinian and American judicial decisions in constitutional cases. However, it appears from the very text of his book that there are significant differences. There is, for instance, a puzzling reference to a provision of the Argentinian constitution requiring countersignature of presidential decrees by a member of the cabinet. To what extent, if any, is the American presidential system modified in Argentina by this institution, which has its proper place in a system of parliamentary government of the British or French type? There is no counterpart at all in the American Constitution to the power of the federal government to suspend a provincial government and to entrust temporarily the administration of a province to a federal "intervenor." This power has been developed upon the basis of a constitutional clause which, going beyond Article IV of the Constitution, provides that the federal government shall intervene in the territory of the provinces to guarantee them the republican form of government. There have been more than a hundred such interventions, mostly for the alleged purpose of safeguarding the integrity of elections. Significantly, the Argentine supreme court has refused to protect the provinces against such intervention upon the ground that the question was a political one whose decision rested exclusively with the political authorities. Both the existence of this institution and its actual working are incompatible with American constitutional principles and testify to the existence of political forces different from those which have shaped the present constitutional structure of the United States. Similarity of constitutional texts and even of their judicial interpretations may hide significant differences in political realities. These deeper issues remain in the background of Doctor Amadeo's book. In his historical chapter he describes the principal legal characteristics of the various successive constitutions. In the main part of the book he 
presents the Argentinian case material with references to and comparisons with parallel American decisions. This material is fascinating, and it whets the reader's appetite for a political and sociological interpretation. The book was completed before constitutional government was suspended in the Argentine. But the fact that neither President Castillo nor, as far as it is known, President Ramirez have found it necessary formally to abolish the constitution should serve as a warning.

Professor Amadeo's book constitutes a pioneering enterprise in several respects. It seems to be the first detailed case study in Latin American constitutional law available to lawyers of the United States. It also constitutes the first contribution by a Puerto Rican scholar to inter-American comparative law, a field to whose cultivation Puerto Rico would seem to be more clearly called than any other part of the Americas. Not only is Puerto Rico's educated class bilingual, but Puerto Rican law also constitutes a unique combination of civil-law and common-law elements. In spite of these advantages Puerto Ricans have so far contributed little to American legal science. But in the last few years an awakening of creative thought has taken place in the island, in which the University of Puerto Rico is playing a prominent role. Professor Amadeo's book is the first result of these efforts.

MAX RHEINSTEIN.*

Brlls and Notes. By William E. Britton. ${ }^{1}$ St. Paul: West Publishing Co. r943. Pp. xx, r245. \$5.00.

This book is an excellent picture of the law of bills and notes as taught in the better standard courses offered in our law schools. Carrying out the purpose of every hornbook, it gives the student or any other person desiring to approach the law of bills and notes a description of the subject as it is covered in the classroom and a sufficient amount of information to aid him in his preliminary mastery of that phase of the law. In this respect, Britton's work is the best presentation yet of what a student should have to master in such a course.

Equipped with an historical introduction which takes into account recent developments in the field, it expands the "common-law" theory of negotiable instruments against the background of the Negotiable Instruments Law. Although, like most books of this class, it contains $e x$ cathedra statements about the common law so dear to the heart of the American law professor, ${ }^{2}$ it is surprisingly free from inaccuracies, though

* Max Pam Professor of Comparative Law, University of Chicago; Visiting Professor, University of Puerto Rico.

1 Professor of Law, College of Law, University of Illinois.

2 E.g." "The law of negotiable instruments can be searched for three hundred years and no case found, save two situations, where any term of a negotiable instrument is permitted to be found in a separate writing " (p. 67), but see such cases cited 